\title{
EPISTEMOLOGI ILMU DALAM PERSPEKTIF ISLAM
}

\author{
Hikmah \\ Pascasarjana IAIN Palangka Raya \\ Email : hikmahpky76@gmail.com \\ Muslimah \\ Pascasarjana IAIN Palangka Raya \\ Email : muslimah.abdulaziz@iain-palangkaraya.ac.id \\ Sardimi \\ Pascasarjana IAIN Palangka Raya \\ Email : sardimi@iain-palangkaraya.ac.id
}

\begin{abstract}
Abstrak : Epistemologi adalah bidang filsafat yang mempersoalkan sifat pengetahuan. Dengan kata lain, epistemologi adalah bidang khusus filsafat yang ingin memperoleh pengetahuan tentang pengetahuan, lama ataupun baru, baik dalam bentuk penyerapan indera yang diperoleh secara sadar. Metode yang digunakan dalam kajian ini adalah studi kepustakaan yaitu menekankan kepada studi terhadap literatur-literatur yang sesuai dengan objek yang dikaji. Epistemologi Islam menguji pengetahuan dari perspektif Islam, bagaimana metodologi yang telah terbukti keabsahannya. Aliran epistemologi Islam, Bayani, Burhani, dan Irfani (intuisi). Pengetahuan mendalam tentang Islam Secara epistemologis adalah Ilmu Allah, termasuk semua yang Dia ciptakan dan pengetahuan yang dianugerahkan kepada manusia.
\end{abstract}

\section{Kata Kunci : Epistemologi Ilmu, Perspektif Islam}

Abstract : Epistemology is a field of philosophy that questions the nature of knowledge. In other words, epistemology is a special field of philosophy that seeks to acquire knowledge about knowledge, old or new, either in the form of consciously acquired sensory absorption. The method used in this study is a literature study, which emphasizes the study of the literature in accordance with the object being studied. Islamic epistemology examines knowledge from an Islamic perspective, how the methodology has been proven to be valid. The epistemological schools of Islam, Bayani, Burhani, and Irfani (intuition). Deep knowledge of Islam Epistemologically is the Knowledge of Allah, including all that He created and the knowledge bestowed upon mankind.

Keywords: Epistemology of Science, Islamic Perspective

\section{Pendahuluan}

Pesatnya perkembangan ilmu pengetahuan tidak menghalangi orang untuk mencari kebenaran. Sebaliknya, semakin banyak orang yang menuntut untuk terus mencari kebenaran berdasarkan teori-teori yang ada untuk menguji teori-teori baru atau membatalkan teori-teori lama. Oleh karena itu, manusia aktif terlibat dalam penelitian ilmiah untuk menemukan solusi dari semua masalah yang mereka hadapi. Yaitu tidak berhenti pada titik tertentu, tetapi terus 
berlanjut seiring waktu ketika dapat memuaskan rasa ingin tahu mereka tentang dunia, metode, dan nilai pengetahuan. Oleh karena itu, epistemologi merupakan bagian dari filsafat ilmu yang secara khusus mempertimbangkan hakikat ilmu (scientific knowledge).

Epistemologi ilmu selalu menjadi sumber yang menarik untuk dipelajari, karena didasarkan pada landasan dan teori pengetahuan manusia. Evolusi yang cepat dari konsepkonsep ilmiah saat ini dan aspek-aspek praktisnya berasal dari struktur pengetahuan yang membentuknya.

Wilayah epistemologi ini menempati posisi yang sangat strategis karena menyangkut mengetahui bagaimana memperoleh pengetahuan yang sebenarnya. Mengetahui bagaimana memperoleh pengetahuan dengan benar sangat erat kaitannya dengan hasil, bentuk pengetahuan. Kedepannya, pengalaman menentukan epistemologi akan sangat mempengaruhi warna dan jenis pengetahuan yang dihasilkan.

Jika teori yang sudah mapan tidak bisa lagi menjelaskan peristiwa, ilmu akan jatuh ke dalam krisis. Dalam krisis ini, para ilmuwan membuat revolusi untuk menciptakan model baru. Jelas hari ini bahwa krisis yang dialami oleh sains modern didorong oleh model pemikiran rasionalis. Oleh karena itu, dialektika ilmiah hanya berfungsi untuk menguji teori, bukan untuk menghasilkan pandangan baru dari ilmu. Perspektif baru ini tercapai ketika pandangan subjek dan objek dapat dilampaui. ${ }^{1}$

Epistemologi Islam mengkaji pengetahuan dari perspektif Islam karena metodologinya telah terbukti keabsahannya. Dalam sejarah perkembangan ilmu pengetahuan, selain kebenaran juga dapat diperoleh dari sudut pandang Islam atau proposisi (epistemologi).

\section{Epistemologi Ilmu}

Epistemologi berasal dari kata Yunani episteme dan logos. Episteme berarti pengetahuan, dan logos sering digunakan untuk menunjukkan pengetahuan yang sistematis. Oleh karena itu, dapat disimpulkan bahwa epistemologi adalah pengetahuan yang sistematis tentang pengetahuan. Istilah ini pertama kali dipopulerkan oleh J.F. Ferrier pada tahun 1854 . Dia menciptakan dua cabang filosofis: epistemologi dan ontologi (on = wujud, apa, logo = teori), ontologi (teori tentang apa). ${ }^{2}$ Istilah lain yang sesuai dengan epistemologi dalam berbagai literatur filsafat kadang disebut logika material, standar, kritik intelektual, dan gnosiologi, dan istilah filsafat pengetahuan sering digunakan di Indonesia. ${ }^{3}$

Conny Semiawan dkk. Menurutnya epistemologi adalah "cabang filsafat yang menjelaskan tentang masalah-masalah filosofis sekita teori pengetahuan, epistemologi berfokus pada makna pengetahuan yang berkaitan dengan konsep pengetahuan, sumber dan norma, jenis pengetahuan, dan sebagainya". ${ }^{4}$ Sedangkan menurut Hardono Hadi Epistemologi adalah "bidang filsafat yang berupaya mempelajari dan mencoba menentukan kodrat dan

\footnotetext{
${ }^{1}$ Anwar Mujahidin, 'Epistemologi Islam: Kedudukan Wahyu Sebagai Sumber Ilmu." (Jurnal Ulumuna Vol 17, Nomor 1, 2013), 61 .

${ }^{2}$ Idzam Fautanu, Filsafat Ilmu, (Jakarta : Referensi, 2012), 162-163.

${ }^{3}$ Surajiyo, Ilmu Filsafat Suatu Pengantar, (Jakarta : PT Bumi Aksara, 2008), 53.

${ }^{4}$ Susanto, Filsafat Ilmu: Suatu Kajian Dalam Demensi Ontologis, Epistemologis, Dan Aksiologis, (Jakarta : PT Bumi Aksara, 2013), 102.
} 
ruang lingkup pengetahuan, pengandaian-pengandaian dan dasarnya, serta pertanggung jawaban atas pernyataan mengenai pengetahuan yang dimiliki". 5

Di sisi lain, objek material epistemologi adalah pengetahuan itu sendiri, dan objek formal adalah esensi pengetahuan. Pengetahuan harus memiliki subjek, untuk mencoba mengetahui sesuatu objek, yaitu kesadaran tentang sesuatu yang ingin diketahui. ${ }^{6}$

Pada awalnya secara etimologi ilmu adalah pengetahuan belaka, semua pengetahuan mengenai apa saja. Arti dari ilmu ini kemudian diperluas untuk merujuk pada semua pengetahuan yang sistematis. Pengertian ilmu tidak jauh berbeda dengan pengetahuan, hanya saja terbatas pada disiplin ilmu nonfisik seperti metafisika. Tentu saja, seperti halnya sains, filsafat adalah pengetahuan yang sistematis, tetapi tidak disebut sains dalam epistemologi Barat, tetapi termasuk ilmu dalam epistemologi Islam. Namun, membatasi pencarian pada area yang dimaksud bukanlah filosofi. ${ }^{7}$

Epistemologi dengan demikian merupakan bidang filosofis yang mempertanyakan persoalan tentang sifat pengetahuan. Dengan kata lain, epistemologi adalah bidang khusus filsafat yang bertujuan untuk memperoleh pengetahuan tentang pengetahuan. Dalam hal ini berupa pengetahuan yang merupakan hasil penyerapan indra yang diperoleh secara sadar, baik yang lama maupun yang baru diperoleh.

\section{Jenis-Jenis Epistemologi Ilmu}

Ada berbagai jenis epistemologi, termasuk epistemologi metafisik, epistemologi skeptis, dan epistemologi kritis.

Pertama epistemologi metafisik, Plato dan Hegel, membahas pengetahuan yang dimulai dari perspektif metafisik (realitas) sebagai dasar dari semua realitas. Perbedaan antara dunia ide Plato dan dunia materi atau fenomena (mungkin merupakan tiruan dari dunia ide) didasarkan pada perbedaan Plato antara episteme dan doxa. ${ }^{8}$ Hal yang sama berlaku untuk epistemologi Hegel, yang dimulai dengan hipotesis metafisik. Baginya, realitas tidak lain adalah perwujudan dari ruh, jadi "termasuk ide" dan "realitas atau kenyataan" adalah hal yang sama. Apa yang ditafsirkan sebagai asli, dan ditafsirkan sebagai asli ataupun nyata. Epistemologi berdasarkan asumsi metafisik disebut epistemologi metafisik.

Kedua epistemologi Skeptis, Rene Descartes menemukan cara yang pasti adalah skeptisisme sistematis. Oleh karena itu, Descartes meragukan keberadaan segala sesuatu dan berpendapat bahwa hanya ada satu hal yang tidak dapat diragukan, yaitu meragukan dirinya sendiri. Keraguan membuktikannya. Dari skeptisisme ini, Descartes ingin membangun filsafat dan ilmu pengetahuan di atas fondasi yang kokoh dan andal. Ini didasarkan pada aksioma dan diurutkan oleh proposisi logis. Aktivitas Descartes dikenal sebagai epistemologi skeptis.

Ketiga epistemologi kritis, penting dimulai dengan pemikiran (pengetahuan dan sains) dan sikap kritis terhadap berbagai asumsi, teori, dan metode yang ada dalam kehidupan kita.

\footnotetext{
${ }^{5}$ Mujamil Qomar, Epistemologi Pendidikan Islam Dari Metode Rasional Hingga Metode Kritik, (Jakarta : Erlangga, 2005$), 3$.

${ }^{6}$ Murthada Muthahhari, Mengenai Epistemelogi ; Sebuah Pembuktian Terhadap Rapuhnya Pemikiran Asing dan Kokohnya Pemikiran Islam, Terj. Mhammad Jawad Bafaqih, (Jakarta: Lentera, 2010), 21-23.

${ }^{7}$ Mulyadhi Kartanegara, Menyibak Tirai Kejahilan Pengantar Epistemologi Islam, (Bandung : Mizan, 2003), 10.

${ }^{8}$ Akhyar Yusuf Lubis, Filsafat Ilmu : Klasik Hingga Kontemporer, (Jakarta : Rajawali Pers, 2014), 58.
} 
Pengetahuan, teori, metode, dan gagasan (lama) saat ini telah dikritik dalam arti menemukan kelemahan/kelemahannya dan upaya untuk mengembangkan metode baru, gagasan baru dapat dijelaskan secara lebih rasional. ${ }^{9}$

\section{Metode Epistemologi}

Pengetahuan yang diperoleh manusia melalui akal, perasaan, dan sebagainya, memiliki metode tersendiri. Yang termasuk dalam teori pengetahuan, diantaranya :

\section{Metode induktif}

Metode Ini adalah metode yang menyimpulkan pernyataan-pernyataan dengan kalimat yang lebih umum. Dapat diterima secara luas bahwa ilmu empiris dicirikan oleh metode induktif. Metode induktif dapat disebut induktif ketika pernyataan individu dihilangkan, seperti deskripsi pengamatan manusia atau studi pernyataan universal.

\section{Deduktif}

Deduksi adalah metode untuk menyimpulkan bahwa data empiris diproses lebih lanjut dalam sistem pernyataan yang konsisten. Yang dibutuhkan dalam metode deduktif adalah perbandingan logis dari kesimpulan itu sendiri.

\section{Positivisme}

Metode ini berakar pada metode positif berdasarkan fakta yang diketahui. Mengabaikan setiap masalah atau penjelasan yang ada di luar kebenaran. Oleh karena itu, metode ini dalam bidang filsafat dan ilmu pengetahuan terbatas pada bidang fenomena.

\section{Kontemplatif}

Metode kontemplatif mengatakan bahwa metode ini memiliki keterbatasan alasan untuk perolehan indera dan pengetahuan manusia, dan objek yang dihasilkan berbeda, sehingga perlu untuk mengembangkan kemampuan untuk alasan tertentu, yang disebut intuisi. Pengetahuan intuitif dapat diperoleh dengan merenungkan dengan cara yang sama seperti yang dilakukan Imam Al-Ghazali.

\section{Dialektika}

Dalam filsafat, dialektika awalnya berarti cara bertanya dan menjawab pertanyaan untuk mendapatkan kejelasan filosofis. Metode ini diajarkan oleh Socrates, tetapi Plato menafsirkannya sebagai argumen logis. Kini Dialektika berarti langkah logis yang mengajarkan aturan dan metode dan analisis ide yang sistematis untuk mendapatkan apa yang terkandung dalam sebuah pandangan. ${ }^{10}$

\section{Epistemologi dalam Ilmu Islam}

Dalam bahasa Arab, kata epistemologi sering digunakan dari nazhariyah alma'rifah, tetapi kata ma'rifah digunakan untuk menunjukkan penggunaan kata "ilm (ilmu) yang berbeda". Ketika kehati-hatian diperlukan, kata ma'rifah berarti pengetahuan manusia bisa menjadi ambigu, sedangkan kata 'ilm (ilmu) berarti kejelasan.

Epistemologi Islam mengkaji pengetahuan dari perspektif Islam, karena metodologinya telah terbukti keabsahannya. Dalam sejarah perkembangan ilmu pengetahuan, dan kebenarannya dapat diperoleh dari perspektif Islam atau usulan (epistemologi), model

\footnotetext{
${ }^{9}$ Akhyar Yusuf Lubis, Filsafat..., 58.

${ }^{10}$ Amsal Bakhtiar, Filsafat Ilmu, (Jakarta : PT. Raja Grafindo Persada, Cet ke 13, 2014), 152-156.
} 
epistemologi positivis telah terbentuk selama beberapa dekade dan akhirnya menjadi filsafat sekitar 20 atau 30 tahun kemudian, hingga muncul perkembangan baru.

Epistemologi Islam khusus ini telah dibahas dalam berbagai kajian yang berkaitan dengan berbagai persoalan yang berkaitan dengan ilmu, pengetahuan, pemahaman, proporsi, logika dan bentuk pemikiran, serta dalam berbagai hal yang berkaitan dengan ego dan jiwa manusia. ${ }^{11}$ Sedangkan Ilmu dalam perspektif Islam secara epistemologis adalah Ilmu Allah yang mencakup segala yang diciptakannya, dan ilmu yang diperoleh (dianugerahkan kepada) manusia guna mengetahui hakekat dirinya. ${ }^{12}$

Dari perspektif epistemologi Islam, tidak dikenal dikotomi antara ilmu agama dan ilmu non-agama (umum). Sains adalah ilmu, berasal dari sumber yang sama, kemudian berkembang sesuai dengan bidang objeknya masing-masing, baik objek material maupun objek formal. Terus-menerus dihadapkan pada fenomena alam, manusia, dan apa pun selain itu. Melalui kaitan inilah ilmu pengetahuan terus berkembang dalam ruang sejarah dari waktu ke waktu.

Dalam Islam, epistemologi tidak berpusat pada manusia, tetapi pada Allah, yaitu Allah adalah sumber pengetahuan dan sumber segala kebenaran. Namun demikian, bukan berarti posisi manusia tidak penting, melainkan manusia adalah pencari ilmu.

\section{Karakteristik Epistemologi Islam}

Ilmu dari sudut pandang Islam tidak sepenuhnya bertentangan dengan sains Barat. Hal ini menunjukkan adanya persamaan dan perbedaan antara keduanya. Misalnya, ilmu diakui oleh Islam sebagai salah satu sarana komunikasi untuk memperoleh pengetahuan, dan juga oleh Barat. Ada alasan menyertai, namun keduanya tidak dapat menyelesaikan semua masalah yang dihadapi manusia, sehingga keduanya tidak mutlak. ${ }^{13}$

Adapun Ciri-ciri atau karakteristik epistemologis yang ada di dunia Islam adalah :

\section{Bersandar pada kekuatan spiritual.}

Kebenaran tidak terbatas pada empirisme, seperti yang diasumsikan oleh positivisme , yang mengandalkan kekuatan mental. Manusia adalah makhluk yang tidak hanya emosional, tetapi juga memiliki akal, hati nurani, dan keyakinan. Kekuatan spiritual yang besar tersimpan dalam iman dan hati nurani. Selain wahyu, kekuatan spiritual seperti intuisi juga telah ditekan oleh keilmuan Barat. Di kalangan pemikir Islam, intuisi menempati posisi terbaik sebagai pendekatan perolehan ilmu, dan intuisi diperoleh dengan berdoa kepada Allah. Intuisi digunakan untuk menyempurnakan proses berpikir di awal suatu masalah ilmiah. Artinya, para pemikir Islam terus menggunakan akal dan nalarnya untuk berpikir tentang masalah pengetahuan, sehingga mereka memiliki pendekatan intuisi. ${ }^{14}$

\section{Hubungan yang harmonis antara akal dan wahyu}

\footnotetext{
${ }^{11}$ Miska Muhammad Amin, Epistemologi Islam: Pengantar Filsafat Pengetahuan Islam, (Jakarta: UI-Press, 2006), 11-12.

${ }^{12}$ N Najmudin., \& Said, S. Epistemologi Dikotomi Ilmu, Jurnal Pendidikan Karakter Vol. 6, Nomor 1, (JAWARA, 2020$), 15$.

13 Mujamil Qomar, Epistemologi Pendidikan Islam: Dari Metode Rasional Hingga Metode Kritik, (Jakarta: Erlangga, 2005), 124.

${ }^{14}$ Mujamil Qomar, Epistemologi..., 127-128.
} 
Isfahani menjelaskan hubungan timbal balik antara wahyu dan akal dalam proses memperoleh pengetahuan dalam bahasa organik yang solid. Menurut Isfahani, akal tidak boleh diturunkan tanpa wahyu, dan dalam pengertian itu wahyu tidak dapat dicapai dengan jelas. Hal ini menunjukkan pada bahwa keduanya saling melengkapi. ${ }^{15}$ Keharmonisan akal dan wahyu menunjukkan bahwa ilmu pengetahuan Islam memiliki nilai-nilai transenden, nilai tertinggi.

\section{Interdependensi akal dengan intuisi}

Dalam Islam, sains dibangun di atas kerja sama akal dan intuisi. Intelek memiliki penalaran terbatas, yang kemudian dilengkapi dengan intuisi yang diberikan atau dibantunya. Jika intuisi kita tidak sistematis, kita memerlukan alasan untuk mensistematisasikan pengetahuan yang diberikan kepada kita. Ini menunjukkan bahwa akal membutuhkan intuisi dan bahwa intuisi membutuhkan akal. Menemukan pengetahuan memungkinkan Anda untuk menggunakan akal dan intuisi, tetapi setiap pendekatan epistemologi memiliki kekuatan dan kelemahannya, sehingga kombinasi keduanya membuat pengetahuan yang diperoleh lebih sempurna. Kombinasi akal dan intuisi dapat dicapai dengan pengetahuan ganda: praktis dan spiritual, eksternal dan spiritual, empiris dan metafisik, atau fisik dan metafisik, sekuler dan seterusnya.

\section{Memiliki Orientasi Teosentris}

Teosentris berasal dari bahasa Yunani Theos, tetapi dari sudut pandang teoretis, Tuhan berarti gagasan bahwa semua proses kehidupan di planet ini kembali kepada Tuhan. Ilmu dalam Islam didasarkan pada wahyu serta fakta dan alasan empiris. Ilmu itu datangnya dari Allah, dan ilmu itu sangat menarik bagi Allah. ${ }^{16}$

Ilmu Islam bersifat universal dan terintegrasi dengan Tuhan atau nilai-nilai-Nya. Oleh karena itu, agama dan kepercayaan dalam ajaran Islam termasuk menggambarkan tiga unsur yang ada dalam diri manusia: kesadaran, pikiran, ucapan, dan perilaku yang saling melengkapi ${ }^{17}$ Dalam Islam, sains mengandung informasi dan pembahasan yang lebih detail daripada sains. Karena ilmu mengumpulkan informasi dari Allah melalui wahyu di luar proses biasa. Dengan kata lain, ada sesuatu dalam sains Islam yang tidak dimiliki sains.

\section{Terikat Nilai}

\footnotetext{
${ }^{15}$ Mujamil Qomar, Epistemologi..., 147-148.

${ }^{16}$ Mujamil Qomar, Epistemologi..., 156.

${ }^{17}$ Mujamil Qomar, Epistemologi..., 157.
} 
Ilmu Islam adalah nilai batas, dipengaruhi oleh dimensi spiritual, wahyu, intuisi dan berpusat pada ketuhanan. Hal ini sangat berbeda dengan sains Barat karena menekankan bahwa sains bersifat netral, tidak berharga, dan tidak terikat pada nilai tertentu. Pernyataan ilmiah yang netral (tidak berharga) dan objektif akan menyebabkan manusia modern memandang manusia dan lingkungan sebagai objek belaka. ${ }^{18}$

\section{Aliran-Aliran Epistemologi Islam}

Berikut ini adalah tiga aliran Epistemoplogi yang umum dipakai dalam kajian Islam, yaitu:

\section{Epistemologi Bayani}

Bayani dalam bahasa Arab berarti penjelasan (explanation). ${ }^{19}$ Epistemologi Bayani adalah model metodologis pemikiran berbasis teks yang juga menggunakan kemungkinan akal untuk memahami dan menemukan kebenaran dari referensi utama, teks (Nash). Upaya ini disebut qiyas (analog) dan istinbath (pengambilan keputusan). ${ }^{20}$

Bayani adalah metode menggunakan teks untuk memperoleh pengetahuan. Metode ini sangat bergantung pada mencari kebenaran dalam teks. Tidak peduli fenomena terjadi dalam realitas, dunia akan mencari panduannya dalam teks. Dalam konteks pemikiran Islam, metode bayani adalah metode tafsir atau takwil yang digunakan oleh para mufassir untuk menggali ilmu Al-Qur'an dan Hadits. ${ }^{21}$

Bahasa filosofi yang sederhana, metode bayani dapat diartikan sebagai model metode berpikir berbasis teks. Dalam hal ini teks adalah suci yang memiliki otoritas penuh menentukan arah kebenaran . Peran intelijen hanya sebagai sebagai pengontrol yang berarti di antaranya berisi dari dari di antaranya dapat dibedakan dengan mengamati hubungan antara makna dan wacana. ${ }^{22}$

\section{Epistemologi Burhani}

Dalam bahasa Arab Al-burhan berarti argumen yang jelas dan terang (alhujjah), dan dalam bahasa Inggris berarti bukti (tanda tangan, keterangan, penjelasan). Sebagai metodologi, pandangan dunia yang lahir dari semangat Yunani didukung oleh Aristoteles dan

\footnotetext{
${ }^{18}$ Mujamil Qomar, Epistemologi..., 162.

19 Muhammad Muslih, Filsafat Ilmu: Kajian Atas Asumsi Dasar Paradigma Dan Kerangka Teori Ilmu Pengetahuan, (Yogyakarta: Belukar, 2006), 165.

${ }^{20}$ Muhammad Muslih, Filsafat..., 167-168.

${ }^{21}$ Al Rasyidin, et al., Filsafat ilmu dalam tradisi Islam, (Medan: Perdana Publishing, 2015), 93.

${ }^{22}$ Ahmad Idrus, Epistimologi Bayani, Irfani Dan Burhani, An-Nidhom: Vol 4 Nomor 1, (Jurnal Manajemen Pendidikan Islam, 2019), 34.
} 
kemudian dibahas secara sistematis dalam Organon-nya. ${ }^{23}$ Epistemologi Burhani mencakup dua metode yaitu deduksi dan induksi. Metode penalaran dimulai dari yang umum ke yang khusus. Pengurang alatnya adalah akal manusia, dan pengetahuan yang diperoleh bersifat universal, sehingga pengetahuan yang diperoleh tidak menciptakan pengetahuan baru. Induksi bekerja dari ke khusus ke umum. Alat yang digunakan dalam berhubungan adalah indera manusia, telinga, mata, mulut, hidung dan tangan. Investigasi dilakukan dan kemudian indra digunakan untuk mencari dan menemukan kebenaran berdasarkan fakta dan data dari tempat kejadian. $^{24}$

\section{Epistemologi Irfani (Intuisi)}

Irfani berasal dari kata Irfan, bentuk dasar (Masdar) dari kata 'Arafa, yang memiliki arti yang sama dengan pengetahuan (Ma'rifah). Dalam bahasa Arab, al-irfan berbeda dengan kata al-'ilm. Al-'ilm menunjukkan perolehan objek pengetahuan dengan transformasi (naql) atau rasionalitas ('aql), dan irfan atau ma'rifat berhubungan pengalaman atau pengetahuan langsung dengan objek pengetahuan. ${ }^{25}$ Biasanya manusia seperti ini telah dilatih (riyadlah) dan mencapai tempat tertinggi (tingkat). Keadaan di mana manusia menerima pengetahuan langsung ini adalah dalam keadaan fana (hancur), menekankan penyatuan manusia dengan Tuhan. ${ }^{26}$

Menurut Suhrawardi, intuisi (irfani) adalah "teori pencapaian, intuisi merupakan suatu yang mendahului teks dan suatu syarat dalam pencapaian makna atau pengalaman spiritual yang menghasilkan bentuk ilmu pengetahuan". Paradigma Intuisi menurut Hasan Hanafi terdiri dari dua aspek, yakni pengalaman spiritual mentah dan aspek analisis yang dilakukan oleh kerja akal. Dengan demikian, model intuitif merupakan akumulasi dari model emosional (pikiran) dan persepsi (burhani). Model intuisi akhirnya diselesaikan dengan pembuktian yang masuk akal. ${ }^{27}$

\footnotetext{
23 Muhammad Abed Al-Jabiri, Formasi Nalar Arab: Kritik Tradisi Menuju Pembebasan Dan Pluralisme Wacana Interreligius, Terj. Imam Khori, (Yogyakarta: Ircishod, 2003), 189-190.

${ }^{24}$ Muhammad Abed Al-Jabiri, Formasi..., 191.

${ }^{25}$ A. Khoduri Sholeh, Wacana Baru Filsafat Islam, (Yogyakarta: Pustaka Pelajar, 2004), 179.

${ }^{26}$ Umi Khusnul Khotimah, Tasawuf Islam Dan Pluralisme, Dalam Sururin, Nilai-Nilai Pluralisme Dalam Islam: Bingkai Gagasan Yang Berserak, (Bandung: Nuansa, 2005), 212-213.

${ }^{27}$ Hassan Hanafi, Islamologi 2: Dari Rasionalisme Ke Empirisme, Terj. Miftah Faqih, (Yogyakarta: Lkis, 2004$), 301$.
} 
Epistemologi irfani bekerja dengan kesatuan. Hal ini seperti dikatakan al-Jabiri menyatakan bahwa pemikiran irfani (tasawuf dalam referensi Islam) menginginkan kesatuan antara agama dan ilmu pengetahuan, atau sebaliknya. ${ }^{28}$

\section{Kesimpulan}

Epistemologi adalah bidang filsafat yang mengeksplorasi atau mempertanyakan esensi pengetahuan. Dengan kata lain, epistemologi adalah bidang filosofis tertentu yang berusaha memperoleh pengetahuan dari pengetahuan. Dalam hal ini berupa pengetahuan indrawi yang diserap secara sadar, baik yang lama maupun yang baru diperoleh. Epistemologi Islam menguji pengetahuan dari perspektif Islam. Epistemologi ilmu dari sudut pandang Islam tidak sepenuhnya bertentangan dengan sains Barat. Hal ini menunjukkan adanya persamaan dan perbedaan antara keduanya. Misalnya, indera diakui oleh Islam sebagai sarana untuk memperoleh pengetahuan dan oleh Barat. Dalam Islam, ilmu dikaitkan dengan nilai-nilai yang dipengaruhi oleh dimensi spiritual, wahyu, intuitif, dan orientasi teosentris. Hal ini sangat berbeda dengan ilmu Barat karena menyatakan bahwa ilmu itu netral, tidak terikat pada nilai tertentu.

\section{Daftar Rujukan}

Al-Jabiri, Muhammad Abed. 2003. Formasi Nalar Arab: Kritik Tradisi Menuju Pembebasan Dan Pluralisme Wacana Interreligius. Terj. Imam Khori. Yogyakarta: Ircishod.

Amin, Miska Muhammad. 2006. Epistemologi Islam: Pengantar Filsafat Pengetahuan Islam. Jakarta: UI-Press.

Bakhtiar, Amsal. 2014. Filsafat Ilmu, Jakarta : PT. Raja Grafindo Persada.

Fautanu, Idzam. 2012. Filsafat Ilmu. Jakarta: Referensi.

Hanafi, Hassan. 2004. Islamologi 2: Dari Rasionalisme Ke Empirisme, Terj. Miftah Faqih. Yogyakarta: Lkis.

Idrus, Ahmad. 2019. Epistimologi Bayani, Irfani Dan Burhani. An-Nidhom: Jurnal Manajemen Pendidikan Islam.

Kartanegara, Mulyadhi. 2003. Menyibak Tirai Kejahilan Pengantar Epistemologi Islam. Bandung: Mizan.

\footnotetext{
${ }^{28}$ Muhammad Abed Al-Jabiri, Formasi..., 304.
} 
Khotimah, Umi Khusnul. 2005. Tasawuf Islam Dan Pluralisme, Dalam Sururin, Nilai-Nilai Pluralisme Dalam Islam: Bingkai Gagasan Yang Berserak. Bandung: Nuansa.

Lubis, Akhyar Yusuf. 2014. Filsafat Ilmu: Klasik Hingga Kontemporer. Jakarta: Rajawali Pers.

Mujahidin, Anwar. 2013. "Epistemologi Islam: kedudukan wahyu sebagai sumber ilmu." Jurnal Ulumuna 17.1.

Muslih, Muhammad. 2006. Filsafat Ilmu: Kajian Atas Asumsi Dasar Paradigma Dan Kerangka Teori Ilmu Pengetahuan. Yogyakarta: Belukar.

Muthahhari, Murthada. 2010. Mengenai Epistemologi; Sebuah Pembuktian Terhadap Rapuhnya Pemikiran Asing Dan Kokohnya Pemikiran Islam. Terj. Muhammad Jawad Bafaqih. Jakarta: Lentera.

Najmudin, N. et al. 2020. Epistemologi Dikotomi Ilmu. Jurnal Pendidikan Karakter JAWARA (Jujur, Adil, Wibawa, Amanah, Religius, Akuntabel). 6(1).

Qomar, M. 2005. Epistemologi Pendidikan Islam: Dari Metode Rasional Hingga Metode Kritik. Jakarta : Erlangga.

Rasyidin, Al. et al. 2015. Filsafat Ilmu Dalam Tradisi Islam, (Medan: Perdana Publishing.

Sholeh, A. Khoduri. 2008. Wacana Baru Filsafat Islam. Yogyakarta: Pustaka Pelajar.

Surajiyo. 2008. Ilmu Filsafat Suatu Pengantar. Jakarta: PT Bumi Aksara.

Susanto. 2013. Filsafat Ilmu: Suatu Kajian dalam Dimensi Ontologis, Epistemologis, dan Aksiologis. Jakarta: Bumi Aksara.

Tim Dosen Filsafat Ilmu Fakultas Filsafat UGM. 2007. Filsafat Ilmu. Yogyakarta: Liberty.

Zed, Mestika. 2014. Metode Penelitian Kepustakaan. Jakarta: Yayasan Pustaka Obor Indonesia.

, Juz I. Beirut: Dar al-Fikr, 1917. 